\title{
Detection of Acidovorax avenae subsp. citrulli in Watermelon Seed Using Immunomagnetic Separation and the Polymerase Chain Reaction
}

\author{
R. R. Walcott and R. D. Gitaitis, University of Georgia, Coastal Plain Experiment Station, Tifton 31793
}

\begin{abstract}
Walcott, R. R., and Gitaitis, R. D. 2000. Detection of Acidovorax avenae subsp. citrulli in watermelon seed using immunomagnetic separation and the polymerase chain reaction. Plant Dis. $84: 470-474$.

An immunomagnetic separation and polymerase chain reaction (IMS-PCR)-based assay was developed for detecting Acidovorax avenae subsp. citrulli in watermelon seed. IMS yielded a 10 -fold increase in recovery of A. avenae subsp. citrulli over direct spread-plating on King's Medium B; however, the presence of seed debris reduced IMS efficiency. Synthetic oligonucleotide primers were designed based on the 16S rRNA gene of a known A. avenae subsp. citrulli strain and tested for specific DNA amplification by PCR. The primers amplified DNA from all A. avenae subsp. citrulli strains tested but also yielded amplicons with several closely related bacteria. IMS-PCR resulted in a 100-fold increase in A. avenae subsp. citrulli detection sensitivity over direct PCR and was unaffected by PCR inhibitors in watermelon seed. The threshold of A. avenae subsp. citrulli detection for IMS-PCR was $10 \mathrm{CFU} / \mathrm{ml}$ in watermelon seed wash, and seedlots with $0.1 \%$ infestation were consistently detected. IMS-PCR represents an efficient and sensitive approach to detecting A. avenae subsp. citrulli in watermelon seedlots.
\end{abstract}

Additional keywords: Citrulus lanatus, watermelon fruit blotch

Bacterial fruit blotch (BFB) is a devastating disease of watermelon and other cucurbits which was first observed in the United States in 1988 (25). Since then, it has been responsible for significant economic losses in many of the watermelonproducing states. In addition, because of the costly lawsuits filed by growers, several watermelon seed companies suspended the sales of watermelon seed in 1995 and, as such, BFB seriously threatened the existence of the United States watermelon industry (12). Acidovorax avenae subsp. citrulli (21,28) (formerly Pseudomonas pseudoalcaligenes subsp. citrulli) is the bacterial causal agent of BFB, and its destructive potential stems from the fact that, under favorable conditions, it spreads rapidly throughout transplant houses and in the field to infect and eventually rot watermelon fruit. One important aspect of the disease is that the pathogen is naturally borne and transmitted by seed which usually serves as the primary inoculum source for BFB outbreaks $(11,19,24,26)$. Chemical control of BFB has been ineffective (19) and the most feasible disease-management strategy has been to eliminate infested seedlots prior to planting. Implementation

Corresponding author: R. Walcott

E-mail: rwalcott@arches.uga.edu

Accepted for publication 5 January 2000.

Publication no. D-2000-0218-01R

(C) 2000 The American Phytopathological Society of this strategy requires rapid, reliable, and sensitive seed-detection assays; however, those currently being used (plating seed washes on semi-selective media, seedling grow-out, and enzyme linked immunosorbent assay [ELISA]) are limited by lack of sensitivity and specificity, large greenhouse space and time requirements, and their destructive nature $(3,6,11)$.

Recently, a polymerase chain reaction (PCR)-based assay has been developed for the detection of seedborne A. avenae subsp. citrulli $(14,15,20)$. Despite the significant start-up costs for equipment and development of specific primers, PCR represents the most efficient seed detection assay for A. avenae subsp. citrulli to date. Unfortunately, DNA amplification by PCR is inhibited by watermelon seed compounds and, to avoid inhibitory effects, a cetyldimethylethylammonium bromide (CTAB) DNA preparation protocol was developed $(1,14)$. Compared to routine bacterial template DNA preparation, which involves boiling cells for $15 \mathrm{~min}$, CTAB DNA extraction reduces the PCR assay's efficiency significantly and involves the use of potentially harmful chemicals (e.g., chloroform and phenol).

The efficiency of template DNA preparation can be improved by immunomagnetic separation (IMS), a process by which small, super-paramagnetic polystyrene beads, coated with specific antibodies, are used to sequester target cells from heterogeneous mixtures (16). By this technique, antibodies, covalently attached to magnetic beads, bind target cells by specific antibody-anti- gen interactions during incubation with cell suspensions. The immunomagnetic bead (IMB)-bacteria complexes are held by magnetic force while non-target cells and inhibitory compounds are rinsed away. Template DNA can be released from IMBbound target cells by boiling for $15 \mathrm{~min}$. Furthermore, bound cells remain viable, and thus can be recovered on semi-selective media $(5,22)$.

Application of IMS as a diagnostic tool in clinical microbiology veterinary medicine and food microbiology has been studied extensively $(2,5,9,22,23,27)$. In those reports, IMS enhanced the sensitivity and efficiency of diagnosis; however, implementation of IMS in phytopathogen detection has been limited $(7,17,18)$. This paper describes the development of an IMS-PCR assay for the detection of $A$. avenae subsp. citrulli in watermelon seed.

\section{MATERIALS AND METHODS}

Polyclonal antibodies. Anti- $A$. avenae subsp. citrulli polyclonal antiserum (antiAAC) was developed by injecting New Zealand white rabbits with antigen prepared from heat-treated $\left(100^{\circ} \mathrm{C}\right.$ for $\left.2 \mathrm{~h}\right)$ whole bacterial cells. Lysed cells were pelleted by centrifugation at $20,000 \times g$ for $15 \mathrm{~min}$ at $4^{\circ} \mathrm{C}$ and the supernatant was collected and adjusted to $\mathrm{pH}$ 7.0. Ammonium sulfate was added until saturation to induce precipitation and the suspension was incubated at $4^{\circ} \mathrm{C}$ overnight. The precipitate was pelleted $(20,000 \times g$ for 15 min at $4{ }^{\circ} \mathrm{C}$ ), resuspended in sterile distilled water, and dialyzed $(50,000$ molecular weight cut-off membrane) in sterile distilled water to remove the ammonium sulfate. Final antigen concentration was adjusted to $300 \mu \mathrm{g}$ of protein $/ \mathrm{ml}$. Rabbits were maintained, immunized, and bled by the University of Georgia Polyclonal Antibody Production Service (Athens, GA). The immunoglobulin $\mathrm{G}$ ( $\mathrm{IgG}$ ) fraction of the anti-AAC serum was purified using an AvidChrom Protein Antibody Purification Kit (Sigma-Aldrich, St. Louis) and a final protein concentration of $2 \mathrm{mg} / \mathrm{ml}$ was obtained. Indirect ELISA was conducted on a wide range of bacteria (Table 1) to determine antibody specificity (13). Approximately $5 \times 10^{6} \mathrm{CFU}$ of each bacterium were incubated with $10 \mu \mathrm{l}$ of coupling buffer (2.93 $\mathrm{g}$ of $\mathrm{NaHCO}_{3}, 1.59 \mathrm{~g}$ of $\mathrm{NaCO}_{3}$ in $800 \mathrm{ml}$ of distilled $\mathrm{H}_{2} \mathrm{O}$ ) in individual wells of a polystyrene microtiter plate (Beckton Dickinson Labware, Oxnard, $\mathrm{CA})$ at $37^{\circ} \mathrm{C}$ for $30 \mathrm{~min}$. Blocking buffer 
(40 $\mu \mathrm{l} ; 0.01 \mathrm{M}$ phosphate-buffered saline [PBS] with $0.1 \%$ bovine serum albumin [PBS-BSA]) was added to each well, followed by gentle agitation and incubation at room temperature for $30 \mathrm{~min}$. Wells were rinsed three times with wash buffer (PBS plus $0.2 \%$ Tween 20 [PBST] ) and $20 \mu \mathrm{l}$ of diluted anti-AAC (1:1000) was added. The reagents were gently mixed for $30 \mathrm{~s}$ and plates were incubated for $30 \mathrm{~min}$ at room temperature. After three rinses with wash buffer, $20 \mu \mathrm{l}$ of secondary antiserum (goat anti-rabbit, conjugated with alkaline phosphatase) was added to each well and incubated for $30 \mathrm{~min}$. Wells were rinsed three times with wash buffer and, after removing excess fluid, $20 \mu \mathrm{l}$ of p-nitrophenyl phosphate (pNPP) was added. Plates were incubated at room temperature until a yellow color change occurred in the positive control, which was a cell suspension (approximately $5 \times 10^{8} \mathrm{CFU} / \mathrm{ml}$ ) of a known $A$. avenae subsp. citrulli strain. The reaction was stopped by the addition of $20 \mu \mathrm{l}$ of $1 \mathrm{~N}$ $\mathrm{HCl}$ and plates were read using a microtiter plate reader (Bio-Tek Instruments Inc., Winooski, VT).

Coating of IMBs. Super-paramagnetic beads, pre-coated with sheep anti-rabbit antibodies (Dynabead M280 sheep antirabbit Dynal, Oslo, Norway), were coated with purified IgG fractions of anti-AAC as instructed by the manufacturers. IMBs were agitated for $2 \mathrm{~min}$ and $500 \mu \mathrm{l}$ (approximately $2 \times 10^{8}$ beads) was removed and placed into a $4-\mathrm{ml}$ vial. IMBs were washed four times with PBS while held by a magnetic particle concentrator (MPC; Dynal, Oslo, Norway), then suspended in $3 \mathrm{ml}$ of PBS. Purified IgG protein $(80 \mu \mathrm{g})$ was added and the IMBs were incubated on a tilt-shaker for $24 \mathrm{~h}$ at $4^{\circ} \mathrm{C}$. The IMBs were rinsed four times with 4 $\mathrm{ml}$ of PBS-BSA and resuspended in $3 \mathrm{ml}$ of PBS-BSA to give a final concentration of approximately $1 \times 10^{7}$ beads $/ \mathrm{ml}$. To verify coating, $100 \mu \mathrm{l}$ of processed IMB was incubated for $1 \mathrm{~h}$ with $100 \mu \mathrm{l}$ of a 1:1000 dilution of goat anti-rabbit antibodies, conjugated with alkaline phosphatase (Sigma-Aldrich). IMBs were washed four times with PBS/BSA and 100 $\mu \mathrm{l}$ of pNPP was added as substrate. IMBs were incubated for $20 \mathrm{~min}$ and removed with the MPC, after which the optical density of the buffer was determined at 405 $\mathrm{nm}$ using an ELISA plate reader. An optical-density value twice that of a negative control (consisting of non-coated beads) was used to indicate successful coating. Coated IMBs were stored in PBS-BSA at $4^{\circ} \mathrm{C}$.

Threshold of cell recovery by IMS. To determine the threshold of $A$. avenae subsp. citrulli recovery by IMS and the effects of watermelon seed debris on cell recovery, serial dilutions of the bacterium ranging from 0 to $1 \times 10^{3} \mathrm{CFU} / \mathrm{ml}$ were generated in 2-ml aliquots of PBS or PBS containing seed debris. The latter was gen- erated by shaking $25 \mathrm{~g}$ of watermelon seed in sterile PBS at $150 \mathrm{rpm}$ on a rotary shaker (Labline Instruments Inc., Melrose Park, IL) for $2 \mathrm{~h}$, removing the seed, and sterilizing the supernatant by autoclaving at $121^{\circ} \mathrm{C}$ and $15 \mathrm{psi}$ of pressure for $15 \mathrm{~min}$. Bacterial suspensions were generated by adding known levels of $A$. avenae subsp. citrulli to glass vials containing either $2 \mathrm{ml}$ of PBS or sterile PBS with seed debris. The number of CFU per treatment was estimated by spread plating $100 \mu \mathrm{l}$ of each suspension onto King's medium B (KMB; 10). Recovery efficiency was determined by incubating $2 \mathrm{ml}$ of each sample with 75 $\mu \mathrm{l}\left(7.5 \times 10^{5}\right.$ beads $)$ of anti-AAC-coated IMBs and gently mixing for $15 \mathrm{~min}$ at room temperature. Beads were rinsed three times with PBS-BSA, resuspended in $50 \mu \mathrm{l}$ of PBS-BSA, and spread plated onto $\mathrm{KMB}$. Plates were incubated at $28^{\circ} \mathrm{C}$ for $48 \mathrm{~h}$ and $A$. avenae subsp. citrulli colonies were counted. This experiment was repeated four times, and two-way analysis of variance (ANOVA) was used to compare the effects of target-cell population level and seed-wash debris on A. avenae subsp. citrulli recovery by IMS.

PCR primer selection. Primers were designed and produced from the DNA sequence for the $16 \mathrm{~S}$ ribosomal RNA (rRNA) gene from a strain of $A$. avenae subsp. citrulli (AAC 94-85). Primers were designated WFB 1 (sense) and 2 (anti- sense), with nucleotide sequences of $5^{\prime}$ GAC CAG CCA CAC TGG GAC-3' and 5'-CTG CCG TAC TCC AGC GAT-3', respectively. Primer WFB 1 was selected from positions 293 to 310 and WFB 2 was from positions 652 to 669 of the $16 \mathrm{~S}$ rRNA gene. These sequences flanked a 360-basepair (bp) segment.

DNA amplification. DNA was amplified from 4 to $10 \mu \mathrm{l}$ of bacterial cell lysates. Each $50-\mu \mathrm{l}$ PCR reaction mixture contained $10 \mathrm{mM}$ Tris- $\mathrm{HCl}(\mathrm{pH} 9.0), 50$ $\mathrm{mM} \mathrm{KCl}, 0.1 \%$ Triton X-100, $1.5 \mathrm{mM}$ $\mathrm{MgCl}_{2}, 200 \mu \mathrm{M}$ of each nucleotide (dATP, $\mathrm{dCTP}, \mathrm{dGTP}$, and dTTP), $0.25 \mu \mathrm{M}$ of each primer, and $1 \mathrm{U}$ of Taq DNA polymerase (Promega Corp., Madison, WI). A 50- $\mu$ l sterile, mineral-oil overlay was added to reduce evaporation. DNA amplification was carried out in a PTC-100 programmable DNA thermal cycler (MJ Research, Watertown MA). The PCR reaction tube was incubated in the thermal cycler at $95^{\circ} \mathrm{C}$ for an initial warm-up period of 1 min, followed by denaturation at $95^{\circ} \mathrm{C}$ for $5 \mathrm{~min}, 30$ cycles of denaturation at $95^{\circ} \mathrm{C}$ for $30 \mathrm{~s}$, annealing of primers at $65^{\circ} \mathrm{C}$ for $30 \mathrm{~s}$, and elongation at $72^{\circ} \mathrm{C}$ for $30 \mathrm{~s}$. PCR was completed by incubating the tubes at $72^{\circ} \mathrm{C}$ for $5 \mathrm{~min}$. Using this protocol, PCR was conducted on DNA extracted from a wide range of bacterial genera (Table 1), including 119 A. avenae subsp. citrulli strains isolated from seed, fruit, and foliage

Table 1. Phytopathogenic bacteria used in the polymerase chain reaction (PCR) and enzyme-linked immunosorbent assay (ELISA) specificity tests with primers WFB 1 and 2 and polyclonal anti-Acidovorax avenae subsp. citrulli polyclonal antiserum (anti-AAC) antibodies

\begin{tabular}{|c|c|c|c|}
\hline Bacterium & Isolates tested & $\mathbf{P C R}^{\mathbf{a}}$ & ELISA $^{\mathbf{b}}$ \\
\hline A. avenae subsp. citrulli & 119 & 119 & 119 \\
\hline A. avenae subsp. avenae & 4 & 4 & 4 \\
\hline A. avenae subsp. konjaci & 1 & 1 & 1 \\
\hline A. avenae subsp. cattleyae & 1 & 1 & 1 \\
\hline Comomonas acidovorans & 1 & 1 & 1 \\
\hline Acidovorax sp. from Calathea sp. & 1 & 1 & 1 \\
\hline C. testeronii & 1 & 0 & 0 \\
\hline Burkholderia cepacia & 21 & 0 & 0 \\
\hline Erwinia chrysanthemi & 1 & 0 & 0 \\
\hline Ralstonia solanacearum & 1 & 0 & 0 \\
\hline A. facilis & 6 & 0 & 6 \\
\hline Pseudomonas fluorescens & 1 & 0 & 0 \\
\hline P. putida & 1 & 0 & 0 \\
\hline P. areuginosa & 1 & 0 & 0 \\
\hline P. coronofaciens & 2 & 0 & 0 \\
\hline$P$. corrugata & 1 & 0 & 0 \\
\hline P. viridiflava & 1 & 0 & 0 \\
\hline P. marginata & 1 & 0 & 0 \\
\hline$P$ syringae pv. syringae & 1 & 0 & 0 \\
\hline P. syringae pv. phaseolicola & 1 & 0 & 0 \\
\hline B. gladioli subsp. allicola & 1 & 0 & 0 \\
\hline Xanthomonas campestris pv. vesicatoria & 2 & 0 & 0 \\
\hline X. campestris pv. campestris & 1 & 0 & 0 \\
\hline$X$. campestris raphini & 1 & 0 & 0 \\
\hline Pantoea ananas & 1 & 0 & 0 \\
\hline Bacillus cereus & 1 & 0 & 0 \\
\hline Agrobacterium radiobacter & 1 & 0 & 0 \\
\hline P. agglomerans & 1 & 0 & 0 \\
\hline Clavibacter michiganensis subsp. michiganensis & 1 & 0 & 0 \\
\hline
\end{tabular}

${ }^{a}$ Numbers of bacterial strains yielding a 360-base-pair DNA fragment with PCR primers WFB 1 and 2 .

b Numbers of bacterial strains giving positive indirect ELISA results with polyclonal anti-AAC antibodies. 
of watermelon and other cucurbits between 1992 and 1998, to determine the specificity and reliability of the primers.

Threshold of detection by IMS-PCR. To determine the ability of IMS-PCR to $\operatorname{detect} A$. avenae subsp. citrulli in the presence of inhibitory seed compounds, 2-ml aliquots of seed wash were spiked with $A$. avenae subsp. citrulli to generate cell suspensions with $1 \times 10^{4}, 1 \times 10^{3}, 1 \times 10^{2}, 1 \times$ $10^{1}$, and $0 \mathrm{CFU} / \mathrm{ml}$. PCR was conducted directly on $4 \mu \mathrm{l}$ of cell lysates from each treatment using WFB 1 and 2. IMS-PCR was conducted on the same cell suspensions by adding $100 \mu \mathrm{l}$ of coated IMBs $(1 \times$ $\left.10^{6} \mathrm{IMBs}\right)$ and incubating at $25^{\circ} \mathrm{C}$ for 15 min with gentle agitation. The IMBs were rinsed twice with PBS-BSA, once with sterile distilled water, and resuspended in $15 \mu \mathrm{l}$ of sterile distilled water. IMB-bound bacterial cells were lysed by boiling for 15 min, and $10 \mu \mathrm{l}$ of cell lysates was used for PCR with WFB 1 and 2 primers. The results of PCR were determined by electrophoresis $(90 \mathrm{~V}$ for $1 \mathrm{~h}$ in $1 \times$ Tris borate EDTA [TBE] buffer) of $10 \mu \mathrm{l}$ of the PCR product on a $1 \%$ agarose gel, followed by staining with ethidium bromide and visualization with ultraviolet light. This experiment was repeated nine times.

IMS-PCR detection of A. avenae subsp. citrulli in watermelon seed. Wa-

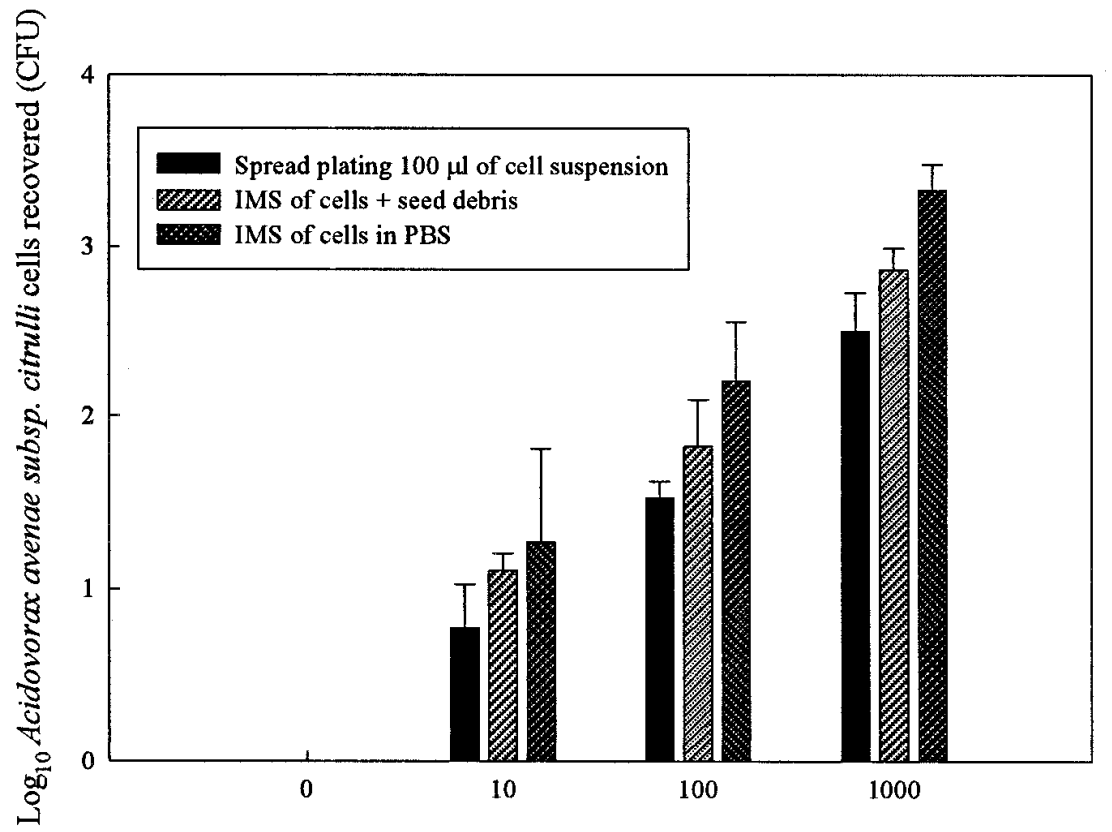

Acidovorax avenae subsp.citrulli cells in suspension (CFU/ml)

Fig. 1. The relationship between initial Acidovorax avenae subsp. citrulli populations and the CFU recovered by immunomagnetic separation (IMS) from cell suspensions in phosphate-buffered saline (PBS), IMS from cell suspensions with seed debris, and direct spread-plating of $100 \mu \mathrm{l}$ of cell suspension. Bars represent standard errors of the means.

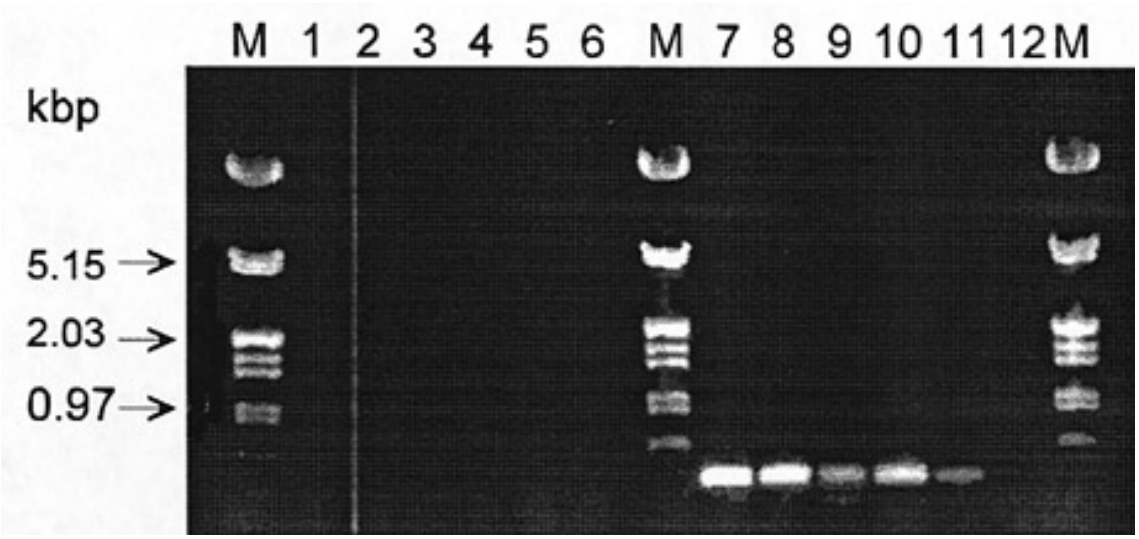

Fig. 2. Comparison of the ability of direct polymerase chain reaction (PCR) and immunomagnetic separation (IMS)-PCR to detect Acidovorax avenae subsp. citrulli from cell suspensions containing a range of CFU in seed wash using primers WFB 1 and 2. Lane M contains a marker consisting of $\lambda$ DNA digested with HindIII and EcoRI; lanes 1 to 5 represent direct PCR on cell suspensions containing $10^{5}, 10^{4}, 10^{3}, 10^{2}, 10^{1}$, and $0 \mathrm{CFU} / \mathrm{ml}$; and lanes 7 to 12 represent IMS-PCR conducted on cell suspensions in seed-wash containing $10^{5}, 10^{4}, 10^{3}, 10^{2}, 10^{1}$, and $0 \mathrm{CFU} / \mathrm{ml}$.

termelon seed $(72 \mathrm{~g})$ was incubated in a 200-ml suspension containing approximately $1 \times 10^{8} A$. avenae subsp. citrulli $\mathrm{CFU} / \mathrm{ml}$ of PBS for 15 min to infest seed. Seed was air-dried and mixed with healthy seed to generate seedlots with $0 \%(0 / 1,000$ seeds), $0.1 \%$ (1/1,000 seeds), $1 \%$ (10/1,000 seeds), $5 \%$ (50/1,000 seeds), and $10 \%$ $(100 / 1,000$ seeds) infestation. Seedlots were incubated with $200 \mathrm{ml}$ of PBST for 4 $\mathrm{h}$ with vigorous agitation on a wrist-action shaker (Burrell Corp., Pittsburgh, PA). The seed suspension was passed through a triple layer of cheesecloth to remove the seeds and $50 \mathrm{ml}$ of seed wash was pelleted by centrifugation at $4,000 \times g$ for $15 \mathrm{~min}$. The pellet was resuspended in $5 \mathrm{ml}$ of PBST, filtered through \#1 filter paper (Whatman, Springfield Mill, UK), and subjected to IMS-PCR with WFB 1 and 2. This study was repeated five times, of which three of the repetitions included seed treated with Thiram. No attempts were made to eliminate the fungicide prior to IMS-PCR. For comparison, indirect ELISA was carried out on $10 \mu$ of seed wash from each artificially infested seedlot as described above.

For CTAB DNA extraction followed by PCR, $50 \mathrm{ml}$ of seed wash was centrifuged at $4,000 \times g$ for $15 \mathrm{~min}$ and the pellet was resuspended in $5 \mathrm{ml}$ of PBS. Acid-washed polyvinylpolypyrillodone (PVPP; $0.5 \mathrm{~g}$ ) was added to the cell suspension and incubated for $30 \mathrm{~min}$ at room temperature with agitation. The acid-washed PVPP was removed by centrifugation at $500 \times g$ for 5 min, and the supernatant was collected. CTAB DNA extraction was conducted to isolate DNA from bacteria present in the seed wash, and PCR was conducted on 2 $\mu \mathrm{g}$ of DNA using primers RST 49 and 51 and the PCR protocol outlined by Minsavage et al. (14).

\section{RESULTS}

Specificity of antibodies. The polyclonal antibodies generated against $A$. avenae subsp. citrulli appeared to be specific at the genus level. By indirect ELISA, positive reactions were observed with all Acidovorax spp. as well as Comomonas acidovorans (Table 1). All other bacteria in the screen tested negative.

Threshold of cell recovery by IMS. Initial A. avenae subsp. citrulli population levels had a statistically significant, positive effect on target-cell recovery by IMS $(P<0.05$; Fig. 1). At all population levels, the numbers of target cells recovered by IMS in the absence of seed debris were at least 10 -fold greater than those obtained by direct spread plating. In the presence of seed debris, IMS also recovered higher numbers of $A$. avenae subsp. citrulli CFU than direct spread plating; however, these numbers were consistently lower than those recovered in the absence of debris (Fig. 1). The negative effect of seed debris on cell recovery was statistically signifi- 
cant $(P<0.05)$ and resulted in a 10 -fold decrease in recovery from cell suspensions containing approximately $1 \times 10^{3}$ and $1 \times$ $10^{2} \mathrm{CFU} / \mathrm{ml}$

Specificity of $16 S$ rRNA primers. Primers WFB 1 and 2 directed the amplification of DNA from $100 \%$ of the A. avenae subsp. citrulli strains tested $(n=119)$, yielding the expected 360-bp DNA amplicon. Several other bacteria also yielded an amplicon of similar size (Table 1). These included $A$. avenae subsp. avenae, $A$. avenae subsp. konjaci, A. avenae subsp. cattleyae, Comomonas testeronii, and an Acidovorax sp. from Calathea sp. There was no positive reaction with any of the other 23 bacteria tested.

Detection threshold of IMS-PCR in watermelon seed wash. DNA amplification was not evident when direct PCR using primers WFB 1 and 2 was conducted on cell lysates suspended in watermelon seed wash (Fig. 2). In contrast, A. avenae subsp. citrulli was detected in $83.3 \%$ of the samples with target-cell populations exceeding $1 \times 10^{4} \mathrm{CFU} / \mathrm{ml}$. However, as target-cell populations decreased, so too did the frequency of detection. In cell suspensions with $1 \times 10^{3}, 1 \times 10^{2}$, and $1 \times 10^{1}$ $\mathrm{CFU} / \mathrm{ml}$, A. avenae subsp. citrulli was detected in $77.8,44.5$, and $42.8 \%$ of the attempts, respectively (Table 2). Amplicons were not produced by IMS-PCR in control treatments.

IMS/PCR detection of A. avenae subsp. citrulli in watermelon seed. Both indirect ELISA and CTAB DNA extraction followed by PCR failed to detect $A$. avenae subsp. citrulli when conducted on watermelon seed washes containing different levels of infested seed. In contrast, IMSPCR detected A. avenae subsp. citrulli in $100 \%$ of the seedlots with $10 \%$ infestation, while seedlots with 5,1 , and $0.1 \%$ infestation were detected in $80 \%$ of the attempts (Table 3). Decreasing seedlot infestation level did not affect pathogen detection by IMS-PCR. In seedlots treated with Thiram, IMS-PCR detected A. avenae subsp. citrulli in all attempts, suggesting the seed treatment had no influence on pathogen detection.

Table 2. Detection of Acidovorax avenae subsp. citrulli by direct polymerase chain reaction (PCR) and immunomagnetic separation (IMS)-PCR in watermelon seed-wash suspensions using primers WFB 1 and 2

\begin{tabular}{lcc}
\hline & \multicolumn{2}{c}{ Frequency of detection } \\
\cline { 2 - 3 } $\begin{array}{l}\text { Population } \\
\text { (CFU/ml) }\end{array}$ & $\begin{array}{c}\text { Direct PCR } \\
(\%)\end{array}$ & $\begin{array}{c}\text { IMS-PCR } \\
(\%)\end{array}$ \\
\hline $10^{5}$ & $(0 / 6) 0$ & $(5 / 6) 83.33$ \\
$10^{4}$ & $(0 / 6) 0$ & $(5 / 6) 83.33$ \\
$10^{3}$ & $(0 / 9) 0$ & $(7 / 9) 77.78$ \\
$10^{2}$ & $(0 / 9) 0$ & $(4 / 9) 44.45$ \\
$10^{1}$ & $(0 / 7) 0$ & $(3 / 7) 42.8$ \\
0 & $(0 / 9) 0$ & $(0 / 9) 0$ \\
\hline
\end{tabular}

${ }^{a}$ A. avenae subsp. citrulli cell population.

\section{DISCUSSION}

IMS is a rapid technique for selectively concentrating and recovering target cells from heterogeneous cell mixtures. The conditions described for IMS, including antibody concentration for coating beads, incubation times, and numbers of rinses, were determined empirically and were appropriate for detection of $A$. avenae subsp. citrulli.

Data from this study indicated that IMS could detect $6.5 \times 10^{1}$ A. avenae subsp. citrulli $\mathrm{CFU} / \mathrm{ml}$ of watermelon seed wash, and cell recovery was directly related to target-cell concentration. IMS resulted in a 10 -fold increase in target-cell recovery over direct spread plating; however, the presence of seed debris significantly reduced cell recovery. It is possible that seed debris may provide surfaces for cell binding, effectively reducing the number of bacterial CFU available for immunocapture. It is also possible that seed debris may trap the IMBs and prevent their magnetic recovery. One simple solution to this problem is to eliminate seed debris prior to IMS by low-speed centrifugation or filtration.

ELISA and PCR detected $100 \%$ of the A. avenae subsp. citrulli strains tested; however, several other bacteria were also detected by both techniques, indicating that neither assay was absolutely specific to $A$. avenae subsp. citrulli. In the case of PCR, this lack of fidelity could have been due to the selection of primers from conserved regions of the 16S rRNA gene which may be common to other bacterial genera $(4,30)$. In general, the bacteria that yielded amplicons with WFB 1 and 2 by PCR were closely related to $A$. avenae subsp. citrulli (28), and several also gave positive reactions with PCR primers RST 49 and 51 (14). Fortunately, A. facilis, an opportunistic pathogen of watermelon often incorrectly identified as A. avenae subsp. citrulli (8), failed to yield a PCR product with primers WFB 1 and 2. Despite the lack of absolute fidelity of the antiserum and primers, the risk of false positive detection of $A$. avenae subsp. citrulli is still minimal because the other Acidovorax spp. are rarely observed in watermelon seed microflora. In addition, if IMS-PCR is used as a pre-screen complement to the seedling grow-out assay, false-positive results could be verified. Nevertheless, because of the significant risks associated with seedborne A. avenae subsp. citrulli, efforts will be made to develop PCR primers with greater levels of specificity.

IMS-PCR detected A. avenae subsp. citrulli from suspensions with approximately $10 \mathrm{CFU} / \mathrm{ml}$ in watermelon seed wash; however, direct PCR failed to detect the target bacterium, demonstrating the presence and potency of PCR inhibitors. Currently, the specific inhibitory compounds are unknown; however, PCR can be inhibited by prevention of cell lysis, degradation of nucleic acids, or limitation of DNA polymerase activity (29). IMSPCR negated the inhibitory effects of watermelon seed-wash compounds; therefore, it is likely that PCR inhibition is due to interference with $\mathrm{Taq}$ DNA polymerase activity rather than the unavailability of template DNA.

Despite the ability of IMS to reduce the effects of watermelon seed-wash inhibitors on DNA amplification, data from this study indicated a reduction in assay reliability as the $A$. avenae subsp. citrulli population decreased. This may be improved by increasing immunocapture time, using more IMBs per sample, or including selective enrichment prior to IMS.

With respect to time, ELISA was the most rapid assay, followed by IMS-PCR, then CTAB DNA extraction and PCR. After the initial 4-h seed-wash period, ELISA took $2.5 \mathrm{~h}$ to complete, while IMSPCR and PCR after CTAB DNA extraction took approximately 3 and $5 \mathrm{~h}$, respectively. However, IMS-PCR detected A. avenae subsp. citrulli in $80 \%$ of seedlots with $0.01 \%$ infestation, while ELISA and CTAB DNA extraction followed by PCR could not detect $A$. avenae subsp. citrulli in seedlots with $10 \%$ infestation. The inability of ELISA to detect the bacterium was not surprising because the detection threshold of the ELISA protocol was approximately $1 \times 10^{4}$ to $1 \times 10^{5} \mathrm{CFU} / \mathrm{ml}$ of distilled water (data not shown). With PCR, Minsavage et al. (14) reported a detection threshold of less than $1 \times 10^{3}$ $\mathrm{CFU} / \mathrm{ml}$. However, we could not duplicate their success after multiple attempts. Perhaps this indicates a problem with repeat-

Table 3. Frequency of detection of Acidovorax avenae subsp. citrulli in watermelon seedlots with different levels of artificial infestation by enzyme-linked immunosorbent assay (ELISA), cetyldimethylethylammonium bromide (CTAB)-DNA extraction, and polymerase chain reaction (PCR) and immunomagnetic separation (IMS)-PCR

\begin{tabular}{lccc}
\hline & \multicolumn{3}{c}{ Seed detection assay } \\
\cline { 2 - 4 } A. avenae subsp. citrulli seed infestation $(\%)$ & IMS/PCR & CTAB-DNA, PCR & ELISA \\
\hline 10 & $(5 / 5) 100$ & 0 & 0 \\
5 & $(4 / 5) 80$ & 0 & 0 \\
1 & $(4 / 5) 80$ & 0 & 0 \\
0.1 & $(4 / 5) 80$ & 0 & 0 \\
0 & $(0 / 5) 0$ & 0 & 0 \\
\hline
\end{tabular}

a CTAB-DNA extraction followed by PCR was conducted with primer set RST 49 and 51. 
ability in the CTAB-DNA extraction protocol due to the need for reagents or other components from specific manufacturers. The CTAB-DNA extraction and PCR assay results were negative; therefore, direct comparisons between it and IMS-PCR could not be made. However, on the basis of time requirements and ease of conducting the protocol, IMS-PCR may be a more efficient assay for detecting seedborne $A$. avenae subsp. citrulli. However, despite the obvious advantages over other seeddetection assays, IMS-PCR must be validated using naturally infested seedlots before it can be recommended for use as a routine seed-detection assay for A. avenae subsp. citrulli.

\section{LITERATURE CITED}

1. Ausubel, F. M., Bent, R., Kingston, R. E., Moore, D. J., Smith, J. A, Silverman, J. G., and Struhl, K. 1987. Current Protocols in Molecular Biology. John Wiley and Sons, N.Y.

2. Biswas, B., Vemulapalli, R., and Dutta, S. K. 1994. Detection of Erlichia risticii from feces in infected horses by immunomagnetic separation and PCR. J. Clin. Microbiol. 32:21472151.

3. Clark, M. F., and Adams, A. N. 1977. Characteristics of the microplate method of enzyme-linked immunosorbent assay for the detection of plant viruses. J. Gen. Virol. 34:475-483.

4. Fox, G. E., Stackebrandt, E., Hespell, R. B., Gibson, J., Maniloff, J., Dyer, T. A., Wolfe, R. S., Balch, W. E., Tanner, R. S., Magrum, L. J., Zablen, L. B., Blakemore, R., Gupta, R., Bonen, L., Lewis, B. J., Stahl, D. A., Luerhsen, K. R., Chen, K. N., and Woese, C. R. 1980. The phylogeny of prokaryotes. Science 209:457-463.

5. Fratamico P. M., Schultz F. J., and Buchanan R. L. 1992. Rapid isolation of Escherichia coli 0157:H7 from enrichment cultures of foods using and immunomagnetic separation method. Food Microbiol. 9:105-113.

6. Gitaitis, R. D. 1993. Development of a seedborne assay for watermelon fruit blotch. Pages 9-18 in: Proc. 1st Int. Seed Trade Assoc. Plant Dis. Comm. Ottawa, Canada.

7. Helias, V., Roux A. C., le, Bertheau, Y., Andrivon, D., Gauthier, .J. P., Jouan, B., and le Roux, A. C. 1998. Characterisation of Er- winia carotovora subspecies and detection of Erwinia carotovora subsp. atroseptica in potato plants, soil and water extracts with PCRbased methods. Eur. J. Plant Pathol. 104:685699.

8. Hodge, N. C., Baird, S. M., Gitaitis, R. G., Hopkins, D. L., and Stall, R. E. 1995. A bacterium related to Acidovorax facilis occurs on watermelon seedlings. (Abstr.) Phytopathology 85(10): 1187

9. Islam, D., and Lindberg A. A. 1992. Detection of Shigella dysenteriae type 1 and Shigella flexneri in feces by immunomagnetic isolation and polymerase chain reaction. J. Clin. Microbiol. 30:2801-2806.

10. King, E. O., Ward, M. K., and Raney, D. E. 1956. Two simple media for the demonstration of pyocyanin and fluorescein. J. Lab. Clin. Med. 44:301-307.

11. Kucharek, T., Perez, Y., and Hodge, C. 1993. Transmission of the watermelon fruit blotch bacterium from infested seed to seedlings. (Abstr.) Phytopathology. 83(4):466.

12. Latin, R. X., and Hopkins, D. L. 1995. Bacterial fruit blotch of watermelon: The hypothetical question becomes reality. Plant Dis. 79:761-765.

13. McLaughlin R. J., and Chen, T. A. 1990. ELISA methods for plant pathogenic prokaryotes. Pages 197-204 in: Serological Methods for Detection and Identification of Viral and Bacterial Plant Pathogens. R. Hampton, E. Ball, and S. De Boer, eds. APS Press, St Paul, MN

14. Minsavage, G. V., Hoover, R. J., Kucharek, T. A., and Stall, R. E. 1995. Detection of the watermelon fruit blotch pathogen on seeds with the polymerase chain reaction. (Abstr.) Phytopathology 85:1162.

15. Mullis, K. B., and Faloona, F. A. 1987. Specific synthesis of DNA in vitro via polymerase catalyzed chain reaction. Pages 335350 in: Methods in Enzymology, Vol. 155. R. Wu, ed. Academic Press, San Diego, CA.

16. Olsvik, O., Popovic, T., Skjerve, E., Cudjoe, K. S., Hornes, E., Ugelstad, J., and Uhlen, M. 1994. Magnetic separation techniques in diagnostic microbiology. Am. Soc. Microbiol. 7(1):43-54.

17. Pain, N. A., Green, J. R., Gammie, F., and O'Connell, R. J. 1994. Immunomagnetic isolation of viable intracellular hyphae of Colletotrichum lindemuthianum (Sacc. \& Magn.) Briosi \& Cav. from infected bean leaves using a monoclonal antibody. New Phytol. 127:223232.

18. Pooler, M. R., Myung, I. S., Bentz, J., Sher- ald, J., and Hartung, J. S. 1997. Detection of Xylella fastidiosa in potential insect vectors by immunomagnetic separation and nested polymerase chain reaction. Lett. Appl. Microbiol. 25:123-126.

19. Rane, K. K., and Latin, R. X. 1992. Bacterial fruit blotch of watermelon: Association of the pathogen with seed. Plant Dis. 76:509-512.

20. Saiki, R .K., Gelfand, D. H., Stoffel, S. Scharf, S. J., Higuchi, R., Horn, G. T., Mullis, K. B., and Erlich, H. A. 1988. Primer-directed enzymatic amplification of DNA with a thermostable DNA polymerase. Science 239:487489.

21. Schaad, N. W., Sowell, G., Goth, R. W., Colwell, R. R., and Webb, R. E. 1978. Pseudomonas pseudoalcaligenes subsp. citrulli subsp. nov. Int. J. Syst. Bacteriol. 28:117125.

22. Skjerve, E., and Olsvik, O. 1991. Immunomagnetic separation of Salmonella from foods. Int. J. Food Microbiol. 14:11-18.

23. Skjerve, E., Rorvik, L. M., and Olsvik, O. 1990. Detection of Listeria monocytogenes in foods by immunomagnetic separation. Appl. Environ. Microbiol. 56(11):3478-3481.

24. Sowell, G., Jr., and Schaad, N. W. 1979. Pseudomonas pseudoalcaligenes subsp. citrulli on watermelon: Seed transmission and resistance of plant introductions. Plant Dis. Rep. 63:437-441.

25. Wall G. C., and Santos V. M. 1988. A new bacterial disease on watermelons in the Mariana Islands. (Abstr.) Phytopathology. 78:1605.

26. Webb, R. E., and Goth, R. W. 1965. A seedborne bacterium isolated from watermelon. Plant Dis. Rep. 49:818-821.

27. Widjojoatmodjo, M. N., Fluit, A. C., Torensma, R., Verdonk, G. P. H. T., and Verhoef, J. 1992. The magnetic immuno-polymerase chain reaction assay for direct detection of Salmonellae in fecal samples. J. Clin. Microbiol. 30:3159-3199.

28. Willems, A., Goor, M., Thielemans, S., Gilis, M., Kersters, K., and De Ley, J. 1992. Transfer of several phytopathogenic Pseudomonas species to Acidovorax as Acidovorax avenae subsp. avenae subsp. nov., comb. nov., Acidovorax avenae subsp. citruli, Acidovorax avenae subsp. cattleyae, and Acidovorax konjaci. Int. J. Syst. Bacteriol. 42:107-119.

29. Wilson, I. G. 1997. Inhibition and facilitation of nucleic acid amplification. Appl. Environ. Microbiol. 63(10):3741-3751.

30. Woese, C. R. 1987. Bacterial evolution. Microbiol. Rev. 51:221-271. 